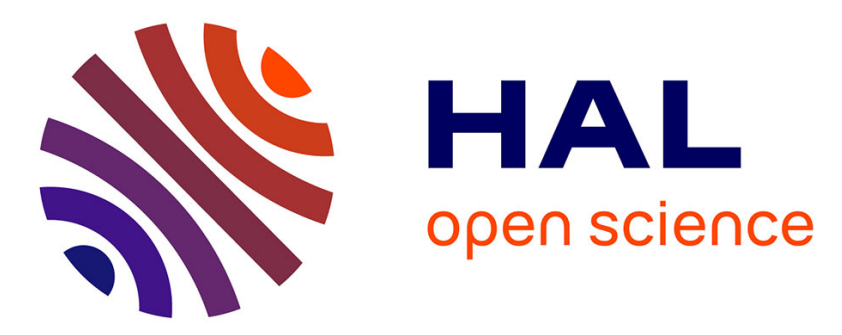

\title{
Reorienting participation, distance and positionality: ethnographic encounters with gender and sexual minority migrants \\ Calogero Giametta
}

\section{- To cite this version:}

Calogero Giametta. Reorienting participation, distance and positionality: ethnographic encounters with gender and sexual minority migrants. Sexualities, 2018. halshs-02043811

\section{HAL Id: halshs-02043811 \\ https://shs.hal.science/halshs-02043811}

Submitted on 21 Feb 2019

HAL is a multi-disciplinary open access archive for the deposit and dissemination of scientific research documents, whether they are published or not. The documents may come from teaching and research institutions in France or abroad, or from public or private research centers.
L'archive ouverte pluridisciplinaire HAL, est destinée au dépôt et à la diffusion de documents scientifiques de niveau recherche, publiés ou non, émanant des établissements d'enseignement et de recherche français ou étrangers, des laboratoires publics ou privés. 
Author: Calogero Giametta. Aix Marseille Univ, CNRS, LAMES, Aix-en-Provence, France

\title{
Reorienting Participation, Distance and Positionality: Ethnographic Encounters with Non-heteronormative Migrants
}

\begin{abstract}
In this article I reflect on how complementing an interview-based methodological approach with participation - as an instrument for knowledge - may be conducive to creating nuanced knowledges about processes of identification, belonging and marginalisation. The thoughts I elaborate on here emerge from two experiences of fieldwork covering a time period that goes from 2011 to the present day with nonheteronormative migrants in the UK and France.
\end{abstract}

Keywords: methodology, queer, participant observation, distance, positionality, social research.

\section{Introduction}

Between 2011 and 2013 I conducted ethnography in London with lesbian, gay, bisexual and trans (LGBT) asylum seekers and refugees, as well as legal representatives, NGO workers whose work revolves around LGBT asylum cases, and activist networks (i.e. support, lobbying, and campaigning groups). This study confirmed my initial skepticism about the notion of 'neutrality' framing the savant social scientist figure - this has already been largely conceptualised within the Social Sciences, although, perhaps not fully implemented into our practices as social researchers. I translated my uneasiness about what I thought was becoming a sort of fixed ethnographer posture into critical standpoints to discuss the dynamic instrumentalisations of sexuality and gender at the hands of current socio-political discourses in the UK. In doing so I put at the centre of the analysis the contested experiences of a migrant group of sexual Others that is either 'excluded from traditional studies of human behavior' (Halberstam, 1998) or, perhaps more worryingly today, overtly sensationalised by the media, and obfuscated by the onset of sexual/gender-based humanitarian interventions (Mai, 2014) at global levels. What partly drew me to this subject was my conviction that researching sexuality and gender as tools for gaining rights within neoliberal migration regimes offered great ethnographic possibilities. But, readily I became aware that it was not the 'attractiveness' of the topic that would proffer a fertile ground for heuristic ethnographic encounters and knowledge. Rather it was more about how much I was willing to give up of myself and 'let myself be affected' (Favret-Saada, 2009, 2012) in the process, namely, to give the self in in order to willingly receive from the subjects of analysis and make some sense of the messiness of their social lives.

In this article I look closely at my ethnographic experiences with non-heteronormative asylum seekers and refugees and simultaneously I refer to the ethnographic approach of Jean Favret-Saada, a French ethnographer who in the 1970s studied witchcraft amongst rural communities in the Bocage, northwest of France (1977). Her work was perceived (and still is now for many) as unorthodox back in the day. First because of the nature of the topic which was largely dismissed as not worthy of scientific attention within 'enlightened' France, but also for her vocal criticism of the methods of ethnographic observation as well as her ideas about the need of the researcher of accepting 'without 
prejudice, to transport oneself as in nature or in love relationships' (Favret-Saada, 2008:5 translation mine) whilst conducting fieldwork. Her approach is present in this text inasmuch as it is present in my own ethnographic work. Here I link her destabilising emic critique of the disciplines of social research, where she was situated, with what I see as a queering sensibility toward methodology:

More generally, my work calls into question anthropology's parochial emphasis on the ideal aspects of the human experience, on the cultural production of "understanding", to employ a term derived from classical philosophy. It seems to me that there is an urgent need to rehabilitate old-fashioned "sensibility", the more so as we are now better equipped to address it than seventeenth century philosophers were (Favret-Saada, 2012: 437).

Following Favret-Saada, let us indeed rehabilitate the notion of sensibility in social research through the prism of Queer scholarship. Certainly, a focus on sensibility is not queer per se, but I would suggest that a focus on sensibility 'oriented' by Queer epistemological standpoints is productive insofar as it challenges academic habitus about what it means to produce academic knowledge. I am not interested in looking for specifically queer 'experiential modes of emotional reflexivity' (Berlant, 2011: 13). This implies that my aim here is not to fix a notion of queer sensibility, yet it is clear that my thoughts, my writing, and my ethnographic practice, in large parts, emerge from my lived experience as a queer migrant as well as my critical commitment to theories such as queer theory, antiracist, and postcolonial ethnographic studies.

Social researchers are fascinated, I would add rightly so, by how sensibility is socially produced. I consider this dimension when I refer to the term but mostly I am interested in examining how one's sensibility arranges one's senses in particular ways in the ethnographic space. This leads me to think through how these arrangements impact on one's understanding of an object/subject of analysis. The etymology of the term sensibility refers to that which can be perceived by the senses (Latin: sensibilitas, from sensibilis 'that can be perceived by the senses', OED). When we are in the fieldsite our senses are alert whilst observing; there, we (researchers) claim to be conducting 'observation' but we know that it isn't just about our sense of vision, yet the word we use to indicate our method reduces it to that. Sensibility, as I use it here, involves an orientation of all the senses. This raises questions about how one perceives or what sort of arrangement of perceptions occurs whilst being there, with the research respondents. My attempt in this article is to pay attention to how one activates her/his sensibility in the fieldwork by putting under critical scrutiny some of 'our' well-established ethnographic methods - namely the rigidity inherent in their names (i.e. participant observation, distance, positionality) and how such rigidity can eclipse important parts of the researcher's sensibility.

\section{Participating in the Observation: The Queerness of the Method}

By paying systematic and zealous attention to the dynamics of everyday life, as inspired by the scholarship of Veena Das (2006), I decided to immerse myself in the lives of the research respondents for an extended period of time (two years). When asking asylum seekers questions pertaining to sexuality, difference and migration trajectories, I realised 
that elicitation methods in isolation would not have been enough to do justice, both analytically and ethically, to the composite narratives of formations of the self (as sexual Others and asylum seekers). In order to inscribe the social discourse produced by the research respondents and to do justice to the complexities of their stories I adopted, not unproblematically, the 'participant observation' approach.

Barbara Tedlock (1991) talks about the shift in cultural anthropology from participant observation toward the observation of participation during the 70s in the US. She says that: 'during participant observation ethnographers attempt to be both emotionally engaged participants and coolly dispassionate observers of the lives of others. In the observation of participation, ethnographers both experience and observe their own and others' coparticipation within the ethnographic encounter' (1991:69). Since the discourses that surfaced in the 70s, the ethnographer today, even the most positivistoriented type, must necessarily locate herself in the text that she produces. It is noteworthy that how ethnography has developed over the years cannot be understood in isolation from more general political-epistemological debates about writing and the representation of otherness (Clifford, 1988). But the debates over participant observation seemed to have mostly focused on the processes of self-examination on the part of the social researcher when writing. I take issue with the expression 'participant observation' prior to the ethnographer's writing phase, that is, when it is applied during the ethnographic encounters.

By the time I began the study with the asylum seekers in London, I had already started to play with the idea of what 'participation'-in the all-encompassing and oft-used phrase 'participant observation' - might entail. This, for me, became an obsessive thought for quite some time; every social researcher I knew was talking about it with such unquestioned confidence yet I couldn't quite figure out how to 'participate'. Participate in what and where? It became clear to me then that before researching I needed to search for the sense of participation in my study. I will provide examples of my search for participating in my fieldwork later in the text, suffice it to say here that participating was the most suitable framing to investigate the fragmentary moments of people who live at the margins of the social field. This initially proved to be difficult but eventually opened up unexpected possibilities that allowed me to form 'organic relationships' (Bourgois, 1996) with respondents by becoming closely involved with them.

As the discipline of Anthropology has taught us for many years (Malinowski, Geertz, Clifford), participant observation requires full commitment from the researcher's point of view in spending long hours with people, in order to immerse oneself into their social worlds, and to establish close relationships with them. The trust that is (supposed to be) established through such long-term relationship may, perhaps, lead to a more nuanced understanding of what is going on. It can also allow the friendly ethnographer to ask questions that one would not be able to ask through even the most complete and wellprepared interview. But can participant observation readily become a 'confusing comfortblanket' (Favret-Saada, 2012) that social researchers make use of when reflecting upon their methods? Is it a non-concept, given its oxymoronic nature? Or even, is it enough to summon the orthodox forces of the quintessential Anthropological method to be content with one's immersion in the research terrain? This, in my view, needed some queering. In her conceptualisation of the queer orientation of Phenomenology, Sara Ahmed tells us that 'we are affected by what we come in contact with. It's not just about approaching or 
arriving at an object but it's more about how we turn to that object' (Ahmed, 2006 emphasis mine). Following Ahmed, queering acts within a given methodology would perhaps direct themselves toward queer objects. But, certainly it's not just a matter of focusing on a queer object of research; a queering methodology might turn to social research methodology by asking questions about the very 'orientation' of social research, namely its sets of well-established truth-finding mechanisms. Thus, part of one's research questions becomes how to reorient social research methods through an internal critique; for instance, asking oneself in the field what participant observation 'really' means and involves (Am I really participating? If so, in what? Or am I just observing even when I claim that I'm doing PO). If we think about our orientations when we navigate the shaky terrain of our fieldworks, then also the term 'observation' of 'participant observation' turns out to be reductive. In fact, being orientated towards our objects is something that is prior and that goes beyond our visual field. Our senses are taken by our orientations, not exclusively our vision, it is a much more embodied and 'emplaced' (Pink, 2009) experience. It involves touch, hearing, the grain of the voice, the silences and the pauses, laughter and so on.

Questioning these taken-for-granted methodological certainties is crucial, beyond the fact that one calls this act queering or not, but I think that if our method of research also questions the significance of the very tools we use, then such method is queering insofar as it does something to shake the normed methods from within. It produces an emic critique (from the inside), which Queer theory has taught us to assume to produce responsible knowledge. Let us now turn our attention to the notion of 'distance' between the researcher and the researched in the ethnographic encounter.

\section{Queering the 'distance' and letting oneself being affected}

In studying LGBT asylum seekers and refugees my queerness allowed for building organic relationships with the research respondents. Thus, through my 'positionality' (I will focus on this term later in the text), I could readily connect with respondents as there often was an underlying sense of sharing experiences amongst us - or of 'having already been there', as it were. In this sense, queer signified a fruitful emic sensibility emerging in the delicate act of exploring the lived experiences of the non-heteronormative subjects who partook in the study.

In my research I found that queering the distance between the researcher and the researched enabled me to create close and informal relationships with the respondents, by meeting them in different everyday life settings, sharing joy and frustration, witnessing and participating in their suffering (without appropriating it), that is, becoming close to them. This proved difficult to sustain at times, particularly when the research subjects are exposed to high level of violence or precarity. In my view, often the 'fetish of the distance' between the researcher and the researched (Kulick and Willson, 1995) is an obstacle and becomes counterproductive in the process of finding one's feet in the unknown territory that one is supposed to map out. Rigidity should not be conflated with scientific value, particularly given the complexities and opacities of fieldwork interactions.

For example, in my fieldwork with the asylum seekers I was faced with a methodological issue that I could only address by breaking the rigidity of the researcher-respondent safety-distance. The issue was how to deal with 'coherence', or lack thereof, both in its 
textual and lived experience forms. Coherence was an epistemological trap for me just as much as it was an ontological one for the gay, lesbian and trans asylum seekers I was speaking to. As for me, I was struggling with fitting into writing all the complexities that were emerging in the fieldwork, some things were going beyond the representational. For the research respondents, coherence was an institutional trap that would define their destiny in the UK or in France, namely, recognition of rights or deportation, therefore could they tell me a different story from the one they had told the UK or the French border control institutions? Along the asylum journey they had to provide coherent and consistent accounts of their experiences of discovering their difference (i.e. 'when did you find out that you were gay?'), the triad fear-violence-trauma, as well as intimate information about their love and sexual relationships. All this then had to be backed up by some relevant evidence, and the narrations of events had to follow a 'plausible' logic. When I started to meet respondents I readily became aware that I had to somehow disrupt the rigidity of the modes of narrativising themselves to which they were getting used by being exposed (very frequently) to the border control institutions. I was set out to queer the space and the affective mode through which these narratives were delivered to me in the role of ethnographer. Let me illustrate this though a note taken from my fieldwork notebook during my ethnography in Marseille:

I've just met Karim for an interview. He is one of my first respondents in Marseille; a Tunisian gay refugee living here for 4 years. We go to a café near Gare St. Charles, we sit at a table inside the café; it's only early October and it's unusually cold for that time of the year in Marseille. Karim looks smart, very polite and willing to talk. It doesn't take too long to go deep into the complexities of his story - from Tunis to Morocco, to then Italy to finally end up in Marseille. He knows his story very well, I'm sure of that from the very moment he starts talking to me. He has repeated this story many times to the social workers, the OFPRA ${ }^{\text {vi }}$, the judges and his extended support network. He tells me things as if in a rush and I can't stop him. I'm getting a bit frustrated, but almost halfway through the interview, he starts telling me about his 'manières', his gestures, and how he always had to tone them down not to 'become effeminate' - as he says. As he refers to that, and then goes on giving me more details of his relationship with his dad and uncle, his body becomes stiffer, he puts his hands under his thighs and keeps sitting on them, lifting his upper body slightly away from the chair and leaning more towards the table. He keeps his body weight on both hands as if to stop them from giving away his 'difference' or lack of normative virility. Now, what does that do to me? In this very moment I seem to re-orient myself towards him in a way that makes me listen to him and be with him there as if we suddenly were in a different place. I look at him more intensely, I recognise that particular act, the act of controlling my gestures; perhaps I have done that in the past myself, perhaps I have used this strategy too for similar reasons. I look at him again and I say, softly, and with a bit of hesitation in my voice (I can hear that in my audio-recording):

Me: Well...Look how much I move mine! Karim: What do you mean? What do you move? Me: My hands! I mean Karim smiles, I smile also, and we both burst into laughter. There was a look. Now we 
start talking, differently.

With Karim I allowed myself to be dispossessed by undoing what he could expect of my role as an interviewer. Through humor, a look, a gesture, we willfully lingered in the opacity of that ethnographic moment where we could queer the ways in which the fixed stories asylum seekers had often been asked to tell could be relived differently. Queering was here a sensibility, which was expressed and shared within research encounters, which did something; it produced specific affects between the researcher and the respondent, thus allowing us to talk and be multiple, contradictory, and even willing to maintain opacity.

Thus far I have stressed that reconfiguring language and destabilising the academic research habitus (rigid languages and sensibilities) are two important conditions for a sound methodology- queering it. Yet, I am aware that ethnographic methods predicated upon queer scholarship are also implicated in the reproduction of hierarchies when speaking of the Others. My intention here is not to offer queering as a panacea to resolve the complex predicaments of ethnographic methodologies and epistemologies. However, it is my conviction that this analytical grammar can be productively mobilised to do autocritique as social researchers (on the methodological level) as well as to underscore the contradictory ways through which respondents' agency is enacted within the structures construed in our social worlds (on the epistemological level).

\section{Finding one's feet OR the ethnographer's 'positionality' in the fieldsite}

My intention is not to saturate the article with detailed accounts of the different places that I consciously occupied, or that I was seen to occupy, as a researcher during the fieldwork - this would be a tedious imposition on the reader, that is; the risk of an autobiographical account gone wrong is always around the corner. But I will partly take up the risk as I find it important to locate myself within the text that emerged from the study, focusing on how my situatedness as a researcher impacted upon the interactions with the subjects of the study. First, I want to express my perhaps banal, but relevant sentiment that during the study with LGBT asylum seekers, I found that being a queer migrant, whose native language was not English, turned out to be an advantage in terms of gaining what one could call 'trust' from research respondents. Often respondents would feel understood given the modes in which my identity was articulated within the space of the research settings. Further, growing up in a socio-cultural context where LGBT embodiments are stigmatised in the public sphere I could quickly recognise the tensions in the narratives presented by respondents pertaining to formations of selfhood, without Othering their understandings and enactments of difference. Thus my 'positionality' would have been of the non-heteronormative, educated male, migrant from a lower middle-class background (perhaps one should add, and so on and so forth) who was intending to enter the lives of non-heteronormative asylum seekers and refugees. Since I started using the word 'positionality' when talking about the various places I was occupying in the study and the sensibility that accompanied my orientations in the fieldsite, the term 'positionality' started to feel very heavy-it seemed that it did not succeed in reflecting what I was trying to convey to my interlocutors. Today, as social researchers we all learn that positionality refers to the fact that a researcher does not 'operate' from a socio-cultural vacuum but that she or he is producing knowledge from a specific perspective, being immersed in a particular value-system. 
Positionality does not hide the fact that I am speaking from a political-ethical position, long gone are the days of neutral 'objectivity'. Then we welcome the term positionality in the Social Sciences, long live positionality. But often, it seems to me that how the term is used (by us, social researchers) makes it devoid of its ethico-political significance and becomes just a word that indicates my fixity in the fieldsite. Positionality thus is primarily understood as the arrival at the fieldsite and the positioning of oneself in a specific way. This can inhibit dynamism, namely, the act of following different orientations or letting the self being oriented; somehow it indicates that which is static. Although positionality differs from the term 'position', which makes it sound as if one should be even more anchored to the ground, it still doesn't get rid of the roots to the posture of the savant ethnographer. Had it not been subsumed by the marketing sector, I would suggest using the word 'positioning'. Although one doesn't have to feel trapped by terminology, it is important to queer tradition-received words because their unquestioned use might readily trigger then reduce their meanings to their most face-value significations. It is important to be mindful of the inherent meaning of 'fixity', stillness (the quality of being stationary) present in the term and remember to always attach its ethico-political value to positionality. Let's let our positionalities in the fieldsite allow us to 'occupy', or be seen to occupy by respondents, different places when engaging in the fieldwork.

My study with non-heteronormative asylum seekers in the UK consisted of three main phases, each one marked by specific developments: i) establishing contacts with gatekeepers to gain access to the migrant population I aimed to interview and study, ii) working as an LGBTI asylum support worker, and iii) direct involvement in theatre workshops and performances by a group of lesbian, gay and bisexual asylum seekers and refugees. These phases did not follow a strict chronological order, in the sense that the interviewing did not stop when the 'participant observation' started, most of these activities occurred simultaneously. My participatory strategies within the group of asylum seekers and refugees I studied did not happen within the context of my work as an asylum support worker, but it mostly occurred during social activities outside of the workspace.

I found that orienting myself toward multiple roles in the research fieldsite provided me with a wealth of information that I couldn't have accessed otherwise- had I been exclusively seen as the ethnographer. Oftentimes it also put me in contradictory situations. When interviewing asylum seekers I wanted to question the pre-fabricated story of the self including their abuses and their necessity of leaving their countries that they were compelled to produce when claiming protection. However, when I was the asylum support worker my job indicated that I was the person that needed to hear a certain story then people were often telling me: 'I'm telling you what you want to hear'. 3.1 Working as an LGBT asylum support worker and my 'participatory being-there' Participating as a tool of knowledge (Favret-Sada, 2012) allowed me to see the specificities of the recurrent problems faced by the migrants I studied. For instance, the fact that one has to continue to live a double-life and not reveal her difference to their conational social networks. Generally, respondents who lived amongst the communities of origin had a fear of one's sexuality being exposed. Further, sexual and gender minority subjects were often deprived of kinship support, or such support was very frail and at times counterproductive, and their sense of isolation was acutely emphasised when having to face institutions such as the UK Border Agency. 
In the summer of 2012 I started to work within a charitable organisation supporting LGBTI asylum as a part-time support worker. I took up the opportunity, for the job involved talking to people who wanted to apply for asylum on the basis of their sexuality and gender identity. I had to provide practical support to those going through the determination process; to help them write the stories that had to be presented during interviews at the Home Office and in court, and to refer claimants to legal aid solicitors that worked in partnership with the organisation. This job at the charity contributed considerably to my understanding of the variety of stories and situations of people in vulnerable conditions as well as to my knowledge of how the system of institutions implicated in the asylum determination process operates in the UK. This information necessarily fed into my descriptions of the complexities of the structural injustice that marks the lives of many research respondents.

Here, I could see some contradictions emerging. As a support worker I was telling asylum claimants to fit their stories with demands of the Border Agency to be successful, at the same time I could see that this was reinforcing the standard narrative of humanitarian support for the sexual and gender minority person coming from those 'homophobic cultures', namely, one simplistic story that obfuscates the reality and therefore the complexities of people's migratory trajectories. This, however, was not just my concern as a split subject as the support worker/researcher at the charity, in fact other colleagues of mine were conscious that their jobs were built on an emergency model, that is, they had to get people out of detention as fast as possible or that they had to help them write their witness statements in a way that could be easily intelligible by the judges, which often meant to advise them to craft their genuineness (Giametta, forthcoming). Being in daily contact with support workers became as important as being in contact with the asylum seekers and refugees, in order to better understand how humanitarian organisations operate, particularly in the field of sexual rights. My being-there, participating in the work, sharing my colleagues' worries, agreeing and disagreeing with them, witnessing the everyday struggles and difficulties of both support workers and the supported was a very enriching experience. But I also started to fear that it could narrow the analytical scope of my research. Firstly, as an asylum support worker I felt limited by the responsibilities of the role in interacting with people outside of institutional spaces. Guaranteeing confidentiality and establishing boundaries are imperative in the research process, but being directly involved in the institutional structure rendered those boundaries more defined. In fact, being an employee within the support organisation made me feel even more responsible towards respondents as I could relate to them from different standpoints. I could better situate the specificities of their material problems when confronted with the institutions.

In my day-to-day job I noted how people felt compelled to shape their identities and behaviours in order to be recognised as genuine sexual dissidents in need of rescuing. I realised that in a pervasive atmosphere of distrust and disbelief characterising the approach of many UKBA caseworkers and adjudicators, it is common to find that people feel the pressure to exaggerate their states of vulnerability, their experience of trauma and their suffering in order to fully fit in the 'victim category'. Initially, the pressure of being granted asylum puts people in a state of anxiety. When people came to the organisation the first piece of advice they were given was that in telling their story it is crucial to always ask oneself the question: 'How did I feel when such and such happened to me?' 
This helps to stress the uniqueness of one's inner feelings, and it shifts the focus from the facts, which are often similar across narratives, to the claimant's subjective feelings. It was within this context that I became aware of how the immigration apparatus, including migrant support organisations, highly values the performative dimension in the telling of a migratory journey. This requirement of working on the inner self to find a 'truth', at times, resembled classical methods in theatre training (see below) to help the actor present a realistic life or event. Whenever witnessing these processes I was reminded of the notion of 'authenticity' and of how problematic a concept is - it is how one tells one's story that provides access to services and not what one's past experiences have been. These, in fact, do not always find validation from the official powers. In this context, the asylum claimant needs to become an 'expert' in communicating her or his vulnerable inner world to the inquisitive ears of the law and institutions.

\section{2 'We're all in the same boat': participating in theatre workshops and performances}

'...They wanted me to enter into it as a partner, to stake the contours of my then existence in the process. Initially, I oscillated between these two pitfalls: if I "participated", fieldwork would become a personal activity, that is to say the opposite of work, but if I attempted to "observe", meaning keeping myself at a distance, I'd have nothing to "observe". In the first case, my scientific project was threatened, but in the second, it was ruined' (Favret-Saada, 2012: 440).

Alongside my experience as an asylum support worker it is important to talk about the place I gradually took as a participant of a theatre group, named International Rainbow, comprising of sexual minority asylum seekers and refugees. More precisely, I would like to discuss the methodological and epistemological effects that emerged from being part of this group, namely the 'how' I got there as well as 'what kind' of data such experience produced. This theatre group materialised from the recent work conducted by the charity organisation where I was a volunteer, prior to my part-time employment within it. Since its inception International Rainbow was a lively amateur community theatre group, which contributed highly to the social capital of the asylum seekers and refugees involved. I was a participant myself and as such I took part in the rehearsals and some of the public performances. Alongside the two volunteer directors who ran the workshops and rehearsals, I was the only non-refugee group member. Initially the other members saw me as 'Calo the charity worker', but after some time the label started to become more blurry and 'Calo' started to be seen more and more as a 'full-time' Rainbow member, this became apparent to me when two participants verbalised it by telling me: 'so now you're here full-time, aren't you? It's good getting to know you here'. As part of the research methods this experience enabled me to imaginatively engage with respondents' social worlds, as Les Back suggests (2007). It also helped me distance myself from the mould of positivist epistemology as the only legitimate research paradigm (Kaptani and Yuval-Davis 2008). This approach was in line with my epistemological intent of queering the study and it allowed for alternative ways of analysing and retelling narratives of identification and belonging. From a more specific methodological point of view, the experience of the theatre was crucial because it enabled me to discuss aspects of the research to which I had not managed to gain access. For instance, the theatre space became my entry point to information concerning respondents' experiences of confinement in detention centres. As a matter of fact, some of the theatre 
group attendees had been in detention for extended time periods and they were willing to share their stories both within the group and with me personally. This was very important as I had scarce data about the living conditions within UK detention centres. Hence, the theatre group unexpectedly added a considerable layer of complexity to the overall analysis. The non-threatening nature of the theatre space allowed people to feel safe and it became perceived to be a place where one could open up whilst creating stories and characters to perform. This always happened in a climate of creativity and mutual respect.

At this stage of the research, the main purpose was to immerse myself in the theatre space to get to know people's stories differently and understand them from a less formal perspective, namely from a point of view which exceeded both my roles of researcher and support worker. Through the common condition of unknowing and learning together - I was very new to the art of acting - any subtle form of hierarchical structure that had started to form previously between me, the researcher, and the researched was challenged. I quickly managed to establish an amicable relationship with the theatre group participants. Having conducted ethnography in different settings and with different groups of asylum seekers and refugees, I now wanted to further trouble my ethnographer's role and reconfigure my relationship with the respondents. Therefore, as a researcher in the fieldsite I wanted to: i) adopt a different point of view (being an amateur actor as the rest of the group in an unknown context); ii) set up more friendly relationships with respondents (learning playfully together); and iii) trigger a different type of information (anecdotal knowledge and more personal accounts).

Generally, participants, in their current political position of asylum seeker or refugee, had told and continued to tell their stories repeatedly in formal contexts, their stories being repeated as many times as to create the illusion of acquiring a life of their own. The theatre work they did challenged the notion of authenticity, with which they constantly struggle in the realm of legal recognition. In fact, participants are required to be 'authentic' when telling their experiences to decision makers and when showing them those intimate feelings that had to be suppressed to avoid public attention and stay safe. Through the theatre practice they had the opportunity to act, namely they could finally tell their stories as well as other stories without feeling the oppressive imperative of being 'authentic' or showing authenticity. On the contrary authenticity had to be eschewed this proved to be visibly liberating for participants.

\section{Conclusion}

I attempted to reconstruct the various stages of my experience as an ethnographer doing fieldwork. In so doing I elaborated on the multiple queerness of my methods when making sense of the fragmented knowledge I gathered in studying a group of nonheteronormative migrants' lives. I stressed the importance of how queering ethnographic interventions should involve a sensibility that goes beyond 'observation' seeking to truly be 'participatory', as well as critique rigid research terminology and practices that reinforce the social research canon. I insisted on the unexpected and unpredictable nature of data sources in the ethnographic process. For instance, I highlighted that through my access to the theatre group I unexpectedly managed to collate information pertaining to ex-detainees' lived experiences.

The queering methodological approach had implications on the knowledge produced with 
my respondents. As a matter of fact, it had an epistemological impact on the overall study. I could not expand much on this point in the pages of this article, but suffice it to say that applying the verb queering in my research methods with LGBT asylum seekers and refugees generated knowledge that: i) destabilise preconceived notions based on conceptual binarisms around sexual minority refugees' lives, ii) problematise the heteroand homo-normative essentialism of legal reasoning and the Home Office approach when sexuality (in the context of migration) is analysed, and iii) challenge the ever-narrowing humanitarian narratives that are available to the research respondents (Giametta, forthcoming). Destabilising the rigidity of academic research practices does not automatically lead to a lack of responsibility toward research respondents. On the contrary, I believe that emic critique in Social Sciences practices is conducive to making one's study important to the respondents. By this I mean that the research methods should emerge from, and produce, a theory that is relevant to the insiders (emic theory, as Boellstorff suggests, 2010) through empirical work during the researcher's participatory phases. This approach allows for a destabilising of the safe and unquestioned 'academic habitus' (Bourgois, 2002) that enormously distances the knowledge produced - through the research encounter - from the subjects being researched. I attempted to use queering as an active verb to question from within the concepts and methods that partly feed our sensibilities as social researchers.

\section{REFERENCES}

Back, Les (2007), The Art of Listening, Oxford: Berg Berlant, Lauren (2011) Cruel Optimism. Durham: Duke University Press Boellstroff, Tom (2010) 'Queer Techne', in Kath Browne and Catherine J. Nash (eds.) Queer Methods and Methodologies: Intersecting Queer Theories and Social Science Research, Surrey: Ashgate Bourgois, Philippe (1996) In Search of Respect: Selling Crack in El Barrio, Cambridge: Cambridge University Press Bourgois, Philippe (2002) 'Ethnography's Troubles and the Reproduction of Academic Habitus', in International Journal of Qualitative Studies in Education, 15(4): 417-420 Clifford, James (1988) The Predicament of Culture:

Twentieth-Century Ethnography, Literature, and Art, Harvard: Harvard University Press. Das, Veena (2006) Life and Words: Violence and the Descent into the Ordinary, Berkeley: University of California Press.

Giametta, Calogero (2014) 'Rescued' subjects: the question of agency and religiosity for non-heteronormative asylum seekers in the UK, in Sexualities, Vol. 17, 583-599 Halberstam, Jack (1998) Female Masculinity, Durham: Duke University Press. Kaptani, Erene and Yuval-Davis Nira (2008) 'Participatory Theatre as a Research Methodology: Identity, Performance and Social Action Among Refugees', in Sociological Research Online 13(5)2. Available at: http://www.socresonline.org.uk/13/5/2.html Kulick, Don and Willson, Margaret (eds.) (1995) Taboo: Sex, Identity, and Erotic Subjectivity in Anthropological Fieldwork, London: Routledge

Favret Jean (1990) Être Affecté in Gradhiva, n 8, 3-10 Saada, Favret Jean (2008) En marge du dossier sur l'empathie en anthropologie (interview with Jeanne Favret-Saada by Cyril Isnart), in Journal des Anthropologues 114- 115 Saada, Favret Jean (2012) Being Affected in HAU : Journal of Ethnographic Theory 2(1) : 435-445 Stoller, Paul (1997) Sensuous Scholarship. Philadelphia: University of Pennsylvania Press Mai, Nicola (2014) Between Embodied Cosmopolitanism and Sexual Humanitarianism: 
The Fractal Mobilities and Subjectivities of Migrants Working in the Sex Industry, in Baby-Collins, V. and Anteby, L. (eds.) Borders, Mobilities and Migrations, Perspectives from the Mediterranean in the 21st Century, Brussels: Peter Lang

Pink, Sarah (2009) Doing Sensory Ethnography, London: Sage Rose, Gillian (1997)

Situating knowledges: positionality, reflexivities and other tactics

Stoller, Paul (1997) Sensuous Scholarship. Philadelphia: University of Pennsylvania

Press

Tedlock, Barbara (1991) From participant observation to the observation of participation:

The emergence of narrative ethnography in Journal of anthropological research, vol $47 \mathrm{n}$ $1,69-94$. 